\title{
Systematization of the impact of wastewater on society and the application of biochar as an alternative to the current crisis.
}

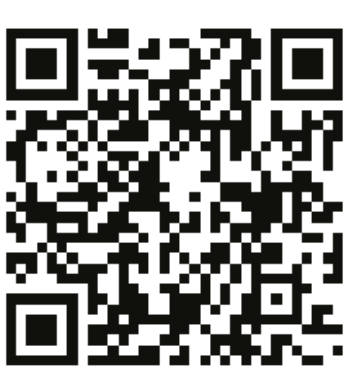

Sistemtización de la afectación en la sociedad de las aguas residuales y la aplicación de biocarbón como alternativa a la crisis actual

Juan Carlos González Delgado

Mater in Territorial Planning and Environmental Management. Universidad Nacional de Tumbes,

Tumbes, Peru. juancarlosgondel@gmail.com. https://orcid.org/oooo-0001-6282-1478

Alfredo Xavier González Delgado

Civil Engineering. University of Guayaquil, Guayaquil, Ecuador.

fitogonzal@gmail.com. https://orcid.org/oooo-0001-7045-9253

Feliciano Javier González Delgado

Mater in Territorial Planning and Environmental Management. Universidad Nacional de Tumbes,

Tumbes, Peru. feliciano@knights.ucf.edu. https://orcid.org/oooo-0001-6282-1478

Gerardo Juan Francisco Cruz Cerro

D. in Environmental Sciences, Universidad Nacional de Tumbes, Tumbes, Peru.

gcruz@untumbes.edu.pe. https://orcid.org/o0oo-0001-6096-0183

\section{Abstract}

Biochar is an effective agent for wastewater treatment, soil remediation and gas retention. This review article reports research on biochar production, technology and application in wastewater treatment. There are different types of biochar production technologies, which emphasize pre-treatment and post-treatment of the feedstock. Biochar is used as an adsorbent for the removal of heavy metals, organic pollutants, nitrogen and phosphorus found in 
wastewater. When a biochar is modified in its original particles, it can achieve a better adsorption capacity, since its surface area increases and its pore structure is improved. In the first instance, this review article focuses on the evaluation of biochar as a technology for the treatment of industrial, municipal and agricultural wastewater. Future challenges in the search for technologies to design an engineered, modified biochar and its application in the removal of pathogens from wastewater would be under discussion. Based on this review article, it can be concluded that biochar represents a new sustainable technology, and that it provides an economical solution for wastewater treatment.

\section{Resumen}

El biocarbón es un agente efectivo para el tratamiento de aguas 110 residuales, remediación de los suelos y para la retención de gases. Este artículo de revisión, relata investigaciones sobre la producción del biocarbón, su tecnología y aplicación en el tratamiento de aguas residuales. Existen diferentes tipos de tecnologías para la producción del biocarbón, las cuales ponen un énfasis en el pre-tratamiento y postratamiento de la materia prima. El biocarbón es usado como adsorbente para la remoción de metales pesados, contaminantes orgánicos, nitrógeno y fosforo que se encuentra en el agua residual. Cuando un biocarbón es modificado en sus partículas originales, este puede lograr una mejor capacidad de adsorción, dado que su área superficial aumenta y la estructura de sus poros se mejora. En primera instancia, este artículo de revisión se enfoca en la evaluación del biocarbón como una tecnología para poder realizar el tratamiento de las aguas residuales industriales, municipales, de agricultura. Retos futuros en la búsqueda de tecnologías para poder diseñar un biocarbón ingenieril, modificado, y su aplicación en la remoción de patógenos del agua residual estaría en discusión. Basado en este artículo de revisión, se puede concluir que el biocarbón representa una nueva tecnología sostenible, y que aporta como una solución económica para el tratamiento de aguas residuales.

\section{Palabras clave/ Keywords}

Wastewater, Production technologies, Organic pollutants, Organic pollutants

Aguas residuales, Tecnologías de producción, Contaminantes orgánicos 


\section{Introduction}

Due to advances in science and technology, there are many chemicals that are used to improve the quality of human life as well as certain consumer products (Wong, Ngadi et al. 2018). However, the abuse and lack of control of chemical and domestic wastes before being discharged into the receiving water body cause negative effects on terrestrial and marine life (Sabeen, Noor et al. 2018). Wastewater contains different types of pollutants such as heavy metals, organic toxic compounds, inorganic substances, pathogenic microorganisms including bacteria, fungi, protozoa, rotifers, algae and viruses (Essa and El-Gayar, 2018). Residual biomass is a solid waste that are regularly dumped or fall into decomposition in the open air without prior treatment causing negative environmental impact (Tomczyk, Sokołowska et al. 2020). There are conventional anaerobic methods for wastewater treatment which occupy little space, are economical, but present limitations in the final effluent results (Gallego-Schmid and Tarpani 2019). On the other hand, there are sophisticated aerobic methods for wastewater treatment, where good results are obtained, but at a high operating cost that end up making a project more expensive (Yenkie, Burnham et al. 2019). Therefore, it is important to use sustainable, economical treatment systems such as the adsorption method through biochar (Blanco-Canqui-2019).

Biochar is a high-carbon and porous product, which is obtained from waste biomass and decomposed by pyrolysis technique (Deng, Zhang et al. 2017). There are a number of feedstock in the form of wastes such as plant residues, futas, sludge, manures, which are used as biomass (Chen, Xie et al. 2018; Chen, Zhang et al. 2017). Adsorption is one of the most widely used technologies for wastewater purification in the removal of organic molecules and heavy metals on an industrial scale (de Caprariis, De Filippis et al. 2017, Huang, Song et al. 2019).

The current objective of the present review is to present the current state of the art related to wastewater treatment using biochar for the treatment of heavy metals and organic pollutants in wastewater.

\section{Materials and Methods}

This is a qualitative-documentary research article. The methodology developed begins with the collection of information on biochar and its main properties. Then, emphasis is placed on production technologies. Likewise, it is considered important to know the effects of heavy metals 
and organic pollutants on the environment. With this previous information, we proceed to the analysis of biochar as an adsorbent medium for aqueous pollutants as well as in wastewater treatment.

Biochar is a porous carbon material, which is produced during the thermochemical decomposition of biomass feedstock without the presence of oxygen. The biomass feedstock can be any organic waste, which includes crop and forestry residues, including wood chips, algae, sewage sludge, compost, and municipal solid waste (Colantoni, Evic et al. 2016, Xiong, Iris et al. 2019). Among the methods for thermochemical decomposition are pyrolysis, hydrothermal carbonization, gasification, torrefaction, microwave heating, which vary in temperature and thermochemical duration (Fang, Zhan et al. 2018). The interest in biochar is transcendental, since it does not lead to two major benefits: First, biochar production is considered to effectively utilize the feedstock of a biomass and thus avoid the emission of greenhouse gases that may deteriorate the environment (Yang, Igalavithana et al. 2018). Secondly, biochar is an effective, economical, and environmentally friendly adsorbent (Cha, Park et al. 2016), in which its extensive surface area is highlighted (Wang, Gao et al. 2017). Biochar can be useful for the adsorption of heavy metals to obtain purified water (Palansooriya, Yang et al. 2020), and it can also be used to improve soil fertility and thus crop yield (Yoo, Beiyuan et al. 2018).

Feedstock, thermochemical decomposition methods, temperature and duration can affect the physical and chemical properties of biochar (Moreira, Noya et al. 2017). The pre-treatment of feedstock as well as the final treatment of biochar are considered as important factors that can affect its properties (Tan, Liu et al. 2016, Yang, Wan et al. 2019). Pretreatment varies depending on the feedstock and the intended use of the biochar, including physical (drying, washing, screening), chemical (the use of chemical agents) and biological (bacterial treatment among others) methods. Post-treatment basically lies in the physical (magnetization) and chemical (corrosion treatment, among others) methods (Usman, Ahmad et al. 2016).

Pretreatment is the first step in the production of biochar, where there are technologies for physical, chemical and biological areas. Within the physical method, there is drying, screening, flattening, washing of the raw material. The lignocellulose plant is usually dried to maintain a constant weight at a temperature of $105 \mathrm{C}$, it can also be ground and then cut into pieces (Essandoh, Wolgemuth et al. 2017). Occasionally, 
drying needs to be considered for certain plants that are used as raw material, because plant materials vary substantially in their moisture content. Chemical pretreatment is actually based on chemical reactions in order to change the properties or compositions of the feedstock materials. One of the known methods is when the feedstock is immersed in a chemical agent or colloidal suspension, and then dried prior to biochar production (Cha, Park et al. 2016). After pretreatment with metal ions in solutions such as $\mathrm{FeCl}_{3}, \mathrm{AlCl}_{3}, \mathrm{MgCl} 2$, the biomass feedstock can be converted into nanocomposite-based biochar where nanoparticles is placed on the surface of biochar(Son, Poo et al. 2018). On the other hand, biomass can also be treated with nanoparticles or natural colloids including carbon nanotubes, graphene and clay, which leads to successful production of nanocomposite-based biochar (Li, Huang et al. 2019). The technology for biological pretreatment is relatively a new concept, which uses biological processes in order to upgrade biomass feedstock to produce biochar (Wang, Gao et al. 2017). Some biomass materials such as sugar beet, bagasse, sludge and animal excrement are first exposed to an anaerobic digestion process, and then the waste generated can be converted into biochar through slow pyrolysis (Wang, Ok et al. 2020). This pre-treatment step with anaerobic digestion leads to the production of biochar with large surface area and better adsorption degree (Wang, Guo et al. 2020). There is also another biological pretreatment, where a large amount of heavy metals are concentrated in the biomass in order to produce biochar (Yang, Wan et al. 2019).

Thermal processes used to convert biomass to biochar include pyrolysis, microwave-assisted pyrolysis, hydrothermal carbonization and gasification (Wang, Xu et al. 2018).

Pyrolysis is a thermochemical process to decompose biomass in an anoxic or hypoxic environment (Cha, Park et al. 2016). Pyrolysis processes are going to depend on temperature, heating rate, and time, these parameters can affect the physicochemical composition of the product properties. The biochar yield decreases with increasing pyrolysis temperature. When the heating rate in turn determines the speed of pyrolysis and its influence on biochar (Cho, Kwon et al. 2017). The time factor causes the biomass to complete its decomposition, while decreasing the yield of biochar production (Mohamed, Kim et al. 2016).

Microwave-assisted pyrolysis is a method to produce bioenergy products including biochar, bio-oil and biogas (Mutsengerere, 
Chihobo et al. 2019). This method offers shorter processing times, requires less energy, is more effective in heat transfer (Duran-Jimenez, Monti et al. 2017).

Hydrothermal carbonization is a method to convert the wet feedstock into a biochar at a temperature of $120-160 \mathrm{C}$. The wet biomass is heated and pressurized in the range of 2-10MPa for 5-240 minutes in a confined system (Zhang, Zhu et al. 2019). This method produces what is known as a hydrocarbon. As the temperature increases, the hydrocarbon contains some functional acidic groups on its surface, which can benefit the adsorption capacity of contaminants (Saha, Saba et al. 2019).

Gasification is a process that converts biomass into gas fuel through the use of gaseous agents. The gasification temperature is usually above $800 \mathrm{C}$ (You, Ok et al. 2017). Biochar obtained from gasification 114 usually contains high levels of alkaline salts and minerals, which can precipitate heavy metals and thus act as a possible solution in soil remediation (Zhang, Zhu et al. 2019). Post-treatment of biochar is normally used in order to increase surface area, pore volume and compounds such as nanoparticles (Tan, Liu et al. 2016). Among the biochar post-treatment methods, there are magnetic procedure, corrosion and milling (Usman, Ahmad et al. 2016, Wang, Gao et al. 2017).

The magnetic method converts biochar into a material where magnetic iron oxide including $\mathrm{Fe}_{3} \mathrm{O}_{4}$, $\mathrm{Fe}_{2} \mathrm{O}_{3}$, or $\mathrm{CoFe}_{2} \mathrm{O}_{4}$ particles are charged inside the biochar (Wang, Zhao et al. 2019). The magnetic biochar modified by being easily coated by aqueous solutions (Son, Poo et al. 2018).

Ball milling is another method that is simple and efficient, which uses kinetic energy to move the balls to break the chemical bond, thereby changing the shape of the particles as nanoparticles are produced (Lyu, Gao et al. 2017). Once the process of this method is completed, an improved biochar is obtained in aspects such as surface area, pore volume, and adsorption capacity (Xiang, Zhang et al. 2020). Bagassebased and ball-milled biochar has good ability to remove and adsorb Ni2+ (Lyu, Gao et al. 2018). This method improves the physical, chemical and adsorption properties of biochar, which allows it to be used in different environments.

Corrosive treatment method such as acid, alkali, oxide are frequently used to modify the surface chemical conditions of biochar. Chemical 
corrosion such as $\mathrm{HCI}, \mathrm{HNO}_{3}, \mathrm{KOH}, \mathrm{NaOH}, \mathrm{KMnO} 4$, and $\mathrm{H}_{2} \mathrm{O} 2$ have been applied for different purposes (Zheng, Yang et al. 2019). Biochar when chemically modified achieves more micropores, extensive surface area, as well as better adsorption capacity.

Environmental deterioration is one of the major issues in the world where there is a great concern about pollution arising from heavy metals known as inorganic pollutants and also pesticides, antibiotics which are one of the organic pollutants that reach the receiving body known as water (Wang and Wang 2019); these pollutants are causing eutrophication, global warming, and soil deterioration (Zhang, Zhou et al. 2018). They are also resistant to biodegradation and thus can reach the food chain by bioaccumulation (Raza, Hussain et al. 2017, Shakoor, Bibi et al. 2018). Heavy metals have ions that happen to be toxic and carcinogenic, which affects the human body (Wong, Ngadi et al. 2018). Anthropogenic activities such as the use of pesticides, industrial manufacturing, mining works, originate organic pollution that mix in water with heavy metals and cause soil weathering that eventually leads to deterioration in water quality (Shakoor, Nawaz et al. 2017).There are other sources that generate organic pollutants such as leachate from municipal solid waste (Shehzad, Bashir et al. 2016). In order to remove heavy metals from water, various methods such as ion exchange, electrolysis, chemical precipitation have been evaluated (Rajapaksha, Alam et al. 2018, Yuan, Cheng et al. 2019). However, adsorption technique is an effective and economical method for the removal of heavy metals from water (Shakoor, Niazi et al. 2016). Adsorbents are accessible materials in the environment, this is why biochar is considered as a good alternative for toxic removal from water (Moreira, Noya et al. 2017, Wu, Huang et al. 2017).

Soil and water protection and treatment has been considered as one of the biggest challenges for mankind (Mostafazadeh, Zolfaghari et al. 2016). Heavy metals are categorized according to their toxicity and chemical behavior in water systems (Shakoor, Niazi et al. 2015, Liu, Xu et al. 2017) . Heavy metals that a high toxic degree such as $\mathrm{Cd}, \mathrm{Ni}, \mathrm{Cr}$, $\mathrm{Hg}, \mathrm{Cu}, \mathrm{Mn}, \mathrm{Pb}, \mathrm{Zn}$, are found in wastes coming from wastewater, mining activities, smelting operations, battery manufacturing, dyes, pigments, electrical appliances (Godlewska, Schmidt et al. 2017). In order to minimize water concentrations of toxic heavy metals, wastewater from domestic discharges, industrial and agricultural activities must be remediated before being deposited on the land surface or in the receiving water body (Shakoor, Niazi et al. 2019). The technique using microbial biomass to treat heavy metals, is expensive, 
consumes considerable energy and produces a toxic sludge. In addition, the results obtained in its treatment are not effective (Kang, $\mathrm{Oh}$ et al. 2015). Thus, the adsorption method with biochar is considered an effective, economical and versatile technique for the removal of heavy metals (Godlewska, Schmidt et al. 2017).

Biochar obtained from plants and animal waste can perfectly adsorb heavy metals from wastewater (Dai, Fan et al. 2017, Zhou, Chen et al. 2017). Arsenic is a toxic metal that appears in wastewater as well as natural water. The adsorption capacity of As3+, improves from 5.7 $\mathrm{ug} / \mathrm{g}$ up to $7.0 \mathrm{ug} / \mathrm{g}$ through the impregnation of $\mathrm{Zn}\left(\mathrm{NO}_{3}\right) 2$ on the biochar surface (Moreira, Noya et al. 2017). When biochar from sugarcane, rice husk, chicken manure is mixed with sawdust, effective results in the removal of $\mathrm{Cd} 2+$ from water are obtained. The increase in the pyrolysis process temperature from $350 \mathrm{C}$ to $650 \mathrm{C}$, in turn determines an increase in $\mathrm{Cd} 2+$ removal capacity (Higashikawa, Conz et al. 2016). Biochar having fresh and dehydrated banana feedstock, manages to have $\mathrm{Pb} 2+$ removal of $359 \mathrm{mg} / \mathrm{g}$ and $193 \mathrm{mg} / \mathrm{g}$ respectively. (Zhou, Chen et al. 2017). Biochar with chicken manure feedstock and mixed with sawdust at a temperature of $650 \mathrm{C}$, achieves adsorption capacity of $11 \mathrm{mg} / \mathrm{g}$ Ni2 + (Higashikawa, Conz et al. 2016). Biochar with seaweed feedstock has plenty of oxygen and is effective for Cu2+ adsorption (Son, Poo et al. 2018).

Organic pollution includes pesticides, herbicides, antibiotics, among others. These pollutants are toxic and reduce dissolved oxygen in water, which causes harm to the aquatic ecosystem as well as human health (Ahmed, Zhou et al. 2016).

Biochar that is made from grass is found to be useful for adsorption of herbicides in aqueous solutions. In order to obtain better results, it is considered that the $\mathrm{pH}$ of being low in the solution (Essandoh, Wolgemuth et al. 2017). Iron, zinc impregnated on a sawdust biochar shows high removal of tetracycline from aqueous solution (Zhou, Chen et al. 2017).

Biochar can also adsorb nutrients such as nitrogen and phosphorus in aqueous phase (Xue, Gao et al. 2016). Ammonium, nitrate and phosphate are the most common forms of nitrogen and phosphorus reaction in wastewater, leading to eutrophication (Xu, Lin et al. 2018). The use of pine sawdust as feedstock to make biochar at a temperature of $300 \mathrm{C}$ shows a high adsorption capacity of $\mathrm{NH}_{4}+$ (Yang, Lou et al. 2018). Additionally, biochar produced from wood waste pre-treated 
with magnesium oxide is effective for the removal ( $\mathrm{Xu}$, Lin et al. 2018) of ammonium and phosphate.

Biochar is an important solution to remediate pollution in the industrial and agricultural sectors (Wang, Gao etal. 2017). Wastewater is a global problem, involving domestic, industrial, commercial and agriculture sectors, where biochar shows great prowess for wastewater treatment.

Industrial water comes from different sources such as mining, smelting, battery, chemical industry, leather manufacturing, among others. Industrial wastewater is dominated by heavy metals and organic pollutants. Biochar mixed with chitosan can be fused in membranes, which is an effective adsorbent of heavy metals in industrial water. The rate of biochar and chitosan could affect the adsorption of copper, cadmium, arsenic and other heavy metals that

117 are in industrial water (Hussain, Maitra et al. 2017). Biochar made from bagasse proves to be a good adsorbent of lead that is held as an effluent in battery manufacturing. The maximum adsorption capacity obtained is $12.7 \mathrm{mg} / \mathrm{g}$, and the adsorption process is directly related to an average $\mathrm{pH}$ value, contact time and dosage (Bharti and Kumar 2018).

Biochar can be combined with filters or other technologies for municipal wastewater treatment. The combination of aluminum and oxyhydroxides with biochar can be applied to recycle and reuse phosphorus from secondary wastewater treatment (Zheng, Wang et al. 2019). The adsorption mechanism of phosphorus is through electrostatic attraction. The treated sludge can produce a biochar as an adsorbent for the ammonium that is present in municipal wastewater. A temperature of $450 \mathrm{C}$ is the optimum to be able to reach its maximum ammonium removal capacity, this process is controlled through chemical adsorption (Tang, Alam et al. 2019). The wastewater coming from waste, can be treated with biochar, which with its high pore surface area helps the respective filtration (Chen, Yan et al. 2019).

The development of agriculture has increased, and thus controls on heavy metals and pesticides must be very robust (Wei, Li et al. 2018). Biochar made with a raw rice base is effective for adsorption of atrazine, which is categorized as one of the common pollutants in agriculture (Mandal, Singh et al. 2017). The adsorption capacity of biochar on pesticides is going to depend on the feedstock, functional materials, and contaminants (Wei, Li et al. 2018). The most common 
heavy metals found in agriculture are $\mathrm{As}, \mathrm{Cu}, \mathrm{Cr}$ and $\mathrm{Pb}$. The adsorption capacity of $\mathrm{Cu} 2+$ and $\mathrm{As}_{5}+$ from wastewater in agriculture is $69.4 \mathrm{mg} / \mathrm{g}$ and $34.1 \mathrm{mg} / \mathrm{g}$ respectively. The adsorption amount on $\mathrm{Cd} 2+$ and $\mathrm{Pb} 2+$ is in the range of $0.4 \mathrm{mg} / \mathrm{g}$ to $12.3 \mathrm{mg} / \mathrm{g}$, and $36 \mathrm{mg} / \mathrm{g}$ to $35 \mathrm{mg} / \mathrm{g}$ respectively (Higashikawa, Conz et al. 2016, Cho, Kwon et al. 2017, Zhou, Chen et al. 2017, Son, Poo et al. 2018). In adsorption mechanism frames electrostatic interactions, ion exchange, intermolecular interrelationship (Wei, Li et al. 2018). Adsorption behavior differs widely for various pollutants in agriculture (Wei, Li et al. 2018). Adsorption capacity is closely related to nano material content, surface area, pore structure (.

\section{Results}

Biochar is a low-cost adsorbent, which can be produced from a variety of materials including forest residues, treated sludge, municipal organic waste, crop residues, manures, which have been used for wastewater treatment. This article reviews the technologies used to produce biochar and emphasizes technologies for feedstock pretreatment, thermal conversion, and post-treatment. It also summarizes that biochar can be applied for the treatment of municipal wastewater, agricultural wastewater, and industrial wastewater. Although some research has been conducted on the application of biochar for wastewater treatment, there are still some gaps in the field.

Research is needed on: (1) developing technologies for biochar to treat pathogens found in domestic wastewater. (2) increasing the practice of municipal and industrial wastewater treatment. (3) to improve the adsorption capacity of heavy metals, organic pollutants, nitrogen and phosphorus. (4) to analyze which would be the best raw material to produce a biochar that can remove pathogens from wastewater. (5) to investigate the method of impregnation of nanoparticles in order to establish which would be the optimal compound for the treatment of pathogens.

\section{Conclusions}

Among the main conclusions of this review article are: (1) Biochar properties are related to the type of feedstock, technology for feedstock pretreatment, thermal process, and biochar post-treatment. The modification of the biochar in its surface area, the formation of functional groups, reaction activities, are activities that turn out to be important in order to create a well-designed biochar, known as an 
engineered carbon. (2) As adjustments are made to biochar manufacturing, a well-engineered carbon is created that removes aqueous pollutants such as heavy metals, organics, nitrogen and phosphorus. (3) Biochar has a potential ability to remove pollutants from industrial, municipal and agricultural wastewater that has been demonstrated at the laboratory level, however, the application of biochar requires further research in the future.

\section{References}

Essa, A. M. and K. E. El-Gayar "Characterization of bacteria isolated from domestic wastewater in Jazan, Saudi Arabia." Doi: 10.5455/egyebb.20181105093735

Chen, H., et al. (2018). A review: advances on absorption of heavy metals in the waste water by biochar. IOP Conference Series: Materials Science and Engineering, IOP Publishing Bristol, United Kingdom. Doi: 10.1088/1757-899x/301/1/01216o

Chen, Y., et al. (2017). "The structure evolution of biochar from biomass pyrolysis and its correlation with gas pollutant adsorption performance." 246: 101-109. Doi: 10.1016/J.biotech.2017.08.138

Ahmed, M. B., et al. (2016). "Progress in the preparation and application of modified biochar for improved contaminant removal from water and wastewater." 214: 836-851. Doi: 10.1016/j.biotech.2016.05.057

Bharti, S. K. and N. J. A. A. W. S. Kumar (2018). "Kinetic study of lead $(\mathrm{Pb} 2+)$ removal from battery manufacturing wastewater using bagasse biochar as biosorbent." 8(4): 119. doi: 10.1007/513201018-0765-z.

Blanco-Canqui, H. J. J. or. E. Q. (2019). "Biochar and water quality." 48(1): 2-15. Doi: 10.2134/jeq2018.06.0248.

Cha, J. S., et al. (2016). "Production and utilization of biochar: A review." 40: 1-15. Doi: 10.1016/j.jiec.2016.06.002

Chen, C., et al. (2019). "Activated petroleum waste sludge biochar for efficient catalytic ozonation of refinery wastewater." 651: 26312640. Doi: 10.1016/j.scitotenw.2018.10.131

Chen, H., et al. (2018). A review: advances on absorption of heavy metals in the waste water by biochar. IOP Conference Series: Materials Science and Engineering, IOP Publishing Bristol, United Kingdom. Doi: 10.1088/1757-899x/301/1/012160 
Cho, D.-W., et al. (2017). "Simultaneous production of syngas and magnetic biochar via pyrolysis of paper mill sludge using $\mathrm{CO}_{2}$ as reaction medium." 145: 1-9. Doi: 10.1016/j.enconmom.2017.04.095

Colantoni, A., et al. (2016). "Characterization of biochars produced from pyrolysis of pelletized agricultural residues." 64: 187-194. Doi: 10.1016/j.rser.2016.06.003

Dai, L., et al. (2017). "Production of bio-oil and biochar from soapstock via microwave-assisted co-catalytic fast pyrolysis." 225: 1-8. Doi: 10.1016/j.biotech.2016.11.017

de Caprariis, B., et al. (2017). "Pyrolysis wastewater treatment by adsorption on biochars produced by poplar biomass." 197: 231238. Doi: 10.1016/j.jenvmom.2017.04.007

Deng, Y., et al. (2017). "Biochar adsorption treatment for typical pollutants removal in livestock wastewater: a review." 71. doi: 10.5772/intechopen.68253.

Duran-Jimenez, G., et al. (2017). "New insights into microwave pyrolysis of biomass: Preparation of carbon-based products from pecan nutshells and their application in wastewater treatment." 124: 113-121. Doi: 10.1016/j.jaap.2017.02.013

Essandoh, M., et al. (2017). "Adsorption of metribuzin from aqueous solution using magnetic and nonmagnetic sustainable low-cost biochar adsorbents." 24(5): 4577-4590. Doi: 10.1007/s11356016-8188-6.

Fang, J., et al. (2018). "Minireview of potential applications of hydrochar derived from hydrothermal carbonization of biomass." 57: 15-21. Doi: 10.1016/j.jiec.2017.08.026

Gallego-Schmid, A. and R. R. Z. J. W. r. Tarpani (2019). "Life cycle assessment of wastewater treatment in developing countries: a review." 153: 63-79. Doi: 10.1016/j.watres.2019.01.010

Godlewska, P., et al. (2017). "Biochar for composting improvement and contaminants reduction. A review." 246: 193-202. Doi: 10.1016/j.biotech.2017.07.095

Higashikawa, F. S., et al. (2016). "Effects of feedstock type and slow pyrolysis temperature in the production of biochars on the removal of cadmium and nickel from water." 137: 965-972. Doi: 10.1016/j.jclemo.2016.07.205 
Huang, Q., et al. (2019). "Biochar-based materials and their applications in removal of organic contaminants from wastewater: state-of-the-art review." 1(1): 45-73. Doi: 10.1007/s42773-019-00006-5

Hussain, A., et al. (2017). "Development of biochar and chitosan blend for heavy metals uptake from synthetic and industrial wastewater." 7(8): 4525-4537. Doi: 10.1007/s13201-017-06047.

Kang, C.-H., et al. (2015). "Bioremediation of lead by ureolytic bacteria isolated from soil at abandoned metal mines in South Korea." 74: 402-407. Doi: 10.1016/j.ecoleng.2014.10,009

$\mathrm{Li}, \mathrm{R}$., et al. (2019). "Conversion of Cu (II)-polluted biomass into an environmentally benign $\mathrm{Cu}$ nanoparticles-embedded biochar composite and its potential use on cyanobacteria inhibition." 216: 25-32. Doi: 10.1016/j.jclepro.2019.01.186

Liu, S., et al. (2017). "Facile synthesis of $\mathrm{Cu}$ (II) impregnated biochar with enhanced adsorption activity for the removal of doxycycline hydrochloride from water." 592: 546-553. Doi: 10.1016/j.scitotenv.2017.03.087

Lyu, H., et al. (2017). "Ball-milled carbon nanomaterials for energy and environmental applications." 5(11): 9568-9585. Doi: 10.1021/acssuschemeng.7bo2170

Lyu, H., et al. (2018). "Effects of ball milling on the physicochemical and sorptive properties of biochar: Experimental observations and governing mechanisms." 233: 54-63. Doi: 10.1016/j.envpol.2017.10.037

Mandal, A., et al. (2017). "Optimization of atrazine and imidacloprid removal from water using biochars: Designing single or multistaged batch adsorption systems." 220(3): 637-645. Doi: 10.1016/j.ijheh.2017.02.010

Mohamed, B. A., et al. (2016). "Microwave-assisted catalytic pyrolysis of switchgrass for improving bio-oil and biochar properties." 201: 121-132. Doi: 10.1016/j.biotech.2015.10.096

Moreira, M., et al. (2017). "The prospective use of biochar as adsorption matrix-A review from a lifecycle perspective." 246: 135-141. Doi: 10.1016/j.biotech.2017.08.041

Mostafazadeh, A. K., et al. (2016). "Electrofiltration technique for water and wastewater treatment and bio-products management: A review." 14: 28-40. Doi: 10.1016/j.jwpe.2016.10.003 
Mutsengerere, S., et al. (2019). "A review of operating parameters affecting bio-oil yield in microwave pyrolysis of lignocellulosic biomass." 104: 328-336. Doi: 10.1016/j.ser.2019.01.030.

Palansooriya, K. N., et al. (2020). "Occurrence of contaminants in drinking water sources and the potential of biochar for water quality improvement: A review." 50(6): 549-611. Doi: 10.1080/10643389.2019.1629803

Rajapaksha, A. U., et al. (2018). "Removal of hexavalent chromium in aqueous solutions using biochar: chemical and spectroscopic investigations." 625: 1567-1573. Doi: 10.1016/j.scitotenv.2017.12.195

Raza, M., et al. (2017). "Groundwater status in Pakistan: A review of contamination, health risks, and potential needs." 47(18): 17131762. Doi: 10.1080/10643389.2017.1400852

122 Sabeen, A. H., et al. (2018). "Quantification of environmental impacts of domestic wastewater treatment using life cycle assessment: a review." 190: 221-233. Doi: 10.1016/j.jclepro.2018.04.053

Saha, N., et al. (2019). "Effect of hydrothermal carbonization temperature on $\mathrm{pH}$, dissociation constants, and acidic functional groups on hydrochar from cellulose and wood." 137: 138-145. Doi: 10.1016/j.jaap.2018.11.018

Shakoor, M. B., et al. (2018). "The evaluation of arsenic contamination potential, speciation and hydrogeochemical behaviour in aquifers of Punjab, Pakistan." 199: 737-746. Doi: 10.1016/j.chemosphere.2018.02.002

Shakoor, M. B., et al. (2017). "Human health implications, risk assessment and remediation of As-contaminated water: a critical review." 601: 756-769. Doi: 10.1016/j.scitotenv.2017.05.223

Shakoor, M. B., et al. (2016). "Remediation of arsenic-contaminated water using agricultural wastes as biosorbents." 46(5): 467-499. Doi: 10.1080/10643389.2015.1109910

Shakoor, M. B., et al. (2015). "Unraveling health risk and speciation of arsenic from groundwater in rural areas of Punjab, Pakistan." 12(10): 12371-12390. Doi: 10.3390/ijerph121012371.

Shakoor, M. B., et al. (2019). "Exploring the arsenic removal potential of various biosorbents from water." 123: 567-579. Doi: 10.1016/j.envant.2018.12.049 
Shehzad, A., et al. (2016). "Simultaneous removal of organic and inorganic pollutants from landfill leachate using sea mango derived activated carbon via microwave induced activation." 14(5): 991-1001. Doi: 10.1515/ijcre-2015-0145.

Son, E.-B., et al. (2018). "Heavy metal removal from aqueous solutions using engineered magnetic biochars derived from waste marine macro-algal biomass." 615: 161-168. Doi: 10.1016/j.scitotenv.2017.09.171

Tan, X.-f., et al. (2016). "Biochar-based nano-composites for the decontamination of wastewater: a review." 212: 318-333. Doi: 10.1016/j.biotech.2016.04.093

Tang, Y., et al. (2019). "Influence of pyrolysis temperature on production of digested sludge biochar and its application for ammonium removal from municipal wastewater." 209: 927-936. Doi: 10.1016/j.jclepro.2018.10.268

Tomczyk, A., et al. (2020). "Biochar physicochemical properties: pyrolysis temperature and feedstock kind effects." 1-25. Doi: 1007/s11157-020-09523-3.

Usman, A. R., et al. (2016). "Chemically modified biochar produced from conocarpus waste increases NO 3 removal from aqueous solutions." 38(2): 511-521. Doi: 10.1007/s10653-015-9736-6.

Wang, B., et al. (2017). "Recent advances in engineered biochar productions and applications." 47(22): 2158-2207. Doi: 10.1080/10643389.2017.1418580

Wang, J. and S. J. J. J. o. C. P. Wang (2019). "Preparation, modification and environmental application of biochar: a review." 227: 1002-1022. Doi: 10.1016/j.jclepro.2019.04.282

Wang, L., et al. (2020). "New trends in biochar pyrolysis and modification strategies: feedstock, pyrolysis conditions, sustainability concerns and implications for soil amendment." Doi: 10.1111/sum.12592.

Wang, S., et al. (2018). Remediation of biochar on heavy metal polluted soils. IOP Conf Ser: Earth Environ Sci. Doi:

Wang, S., et al. (2019). "Biochar-supported nZVI (nZVI/BC) for contaminant removal from soil and water: a critical review." 373: 820-834. Doi: 10.1016/j.jharmat.2019.03.080 
Wang, X., et al. (2020). "Recent advances in biochar application for water and wastewater treatment: a review." 8: e9164. Doi: $10.7717 /$ peerj.9164.

Wei, D., et al. (2018). "Biochar-based functional materials in the purification of agricultural wastewater: fabrication, application and future research needs." 197: 165-180. Doi: 10.1016/j.chemosphere.2017.12.193

Wong, S., et al. (2018). "Recent advances in applications of activated carbon from biowaste for wastewater treatment: a short review."

$\mathrm{Wu}, \mathrm{C}$., et al. (2017). "Arsenic sorption by red mud-modified biochar produced from rice straw." 24(22): 18168-18178. Doi: 10.1007/s11356-017-9466-7.

Xiang, W., et al. (2020). "Enhanced adsorption performance and governing mechanisms of ball-milled biochar for the removal of volatile organic compounds (VOCs)." 385: 123842. Dio: 10.1016/j.cej.2019.123842.

Xiong, X., et al. (2019). "Value-added chemicals from food supply chain wastes: State-of-the-art review and future prospects." 375: 121983. Doi: 10.1016/j.cej.2019.121983.

$\mathrm{Xu}, \mathrm{K}$., et al. (2018). "Recovery of ammonium and phosphate from urine as value-added fertilizer using wood waste biochar loaded with magnesium oxides." 187: 205-214. Doi: 10.1016/j.jclepro.2018.03.206

Xue, L., et al. (2016). "High efficiency and selectivity of MgFe-LDH modified wheat-straw biochar in the removal of nitrate from aqueous solutions." 63: 312-317. Doi: 10-1016/j.jtice.2016.0321.

Yang, H. I., et al. (2018). "Adsorption of ammonium in aqueous solutions by pine sawdust and wheat straw biochars." 25(26): 25638-25647. Doi: 10.1007/s11356-017-8551-2.

Yang, X., et al. (2018). "Characterization of bioenergy biochar and its utilization for metal/metalloid immobilization in contaminated soil." 640: 704-713. Doi: 10.1016/j.scitotenv.2018.05.298

Yang, X., et al. (2019). "Surface functional groups of carbon-based adsorbents and their roles in the removal of heavy metals from aqueous solutions: a critical review." 366: 608-621. Doi: 10.1016/j.cej.2019.02.119.

Yenkie, K. M., et al. (2019). Generating Efficient Wastewater Treatment Networks: an integrated approach comprising of 
contaminant properties, technology suitability, plant design, and process optimization. Computer Aided Chemical Engineering, Elsevier. 46: 1603-1608. Doi: 10.1016/B978-0-12-8186343.50268-X

Yoo, J.-C., et al. (2018). "A combination of ferric nitrate/EDDSenhanced washing and sludge-derived biochar stabilization of metal-contaminated soils." 616: 572-582. Doi: 10.1016/jscitotenv.2017.10.310

You, S., et al. (2017). "A critical review on sustainable biochar system through gasification: energy and environmental applications." 246: 242-253. Doi: 10.1016/j.biotech.2017.06.177

Yuan, Z., et al. (2019). "Preparation, characterization and performance of an electrospun carbon nanofiber mat applied in hexavalent chromium removal from aqueous solution." 77: 75-84. Doi: $125 \quad$ 10.1016/j.jes.2018.06.016.

Zhang, Y., et al. (2018). "Optical properties and composition changes in chromophoric dissolved organic matter along trophic gradients: Implications for monitoring and assessing lake eutrophication." 131: 255-263. Doi: 10.1016/j.watres.2017.12.051

Zhang, Z., et al. (2019). "Insights into biochar and hydrochar production and applications: a review." 171: 581-598. Doi: 10.1016/j.energy.2019.01.035

Zheng, Y., et al. (2019). "Reclaiming phosphorus from secondary treated municipal wastewater with engineered biochar." 362: 460-468. Doi: 10.1016/j.cej.2019.01.036.

Zheng, Y., et al. (2019). "Facile one-step synthesis of graphitic carbon nitride-modified biochar for the removal of reactive red 120 through adsorption and photocatalytic degradation." 1(1): 8996. Doi: 10.1007/s4273-019-00007-4.

Zhou, N., et al. (2017). "Biochars with excellent Pb (II) adsorption property produced from fresh and dehydrated banana peels via hydrothermal carbonization." 232: 204-210. Doi: 10.1016/j.biotech.2017.01.074 


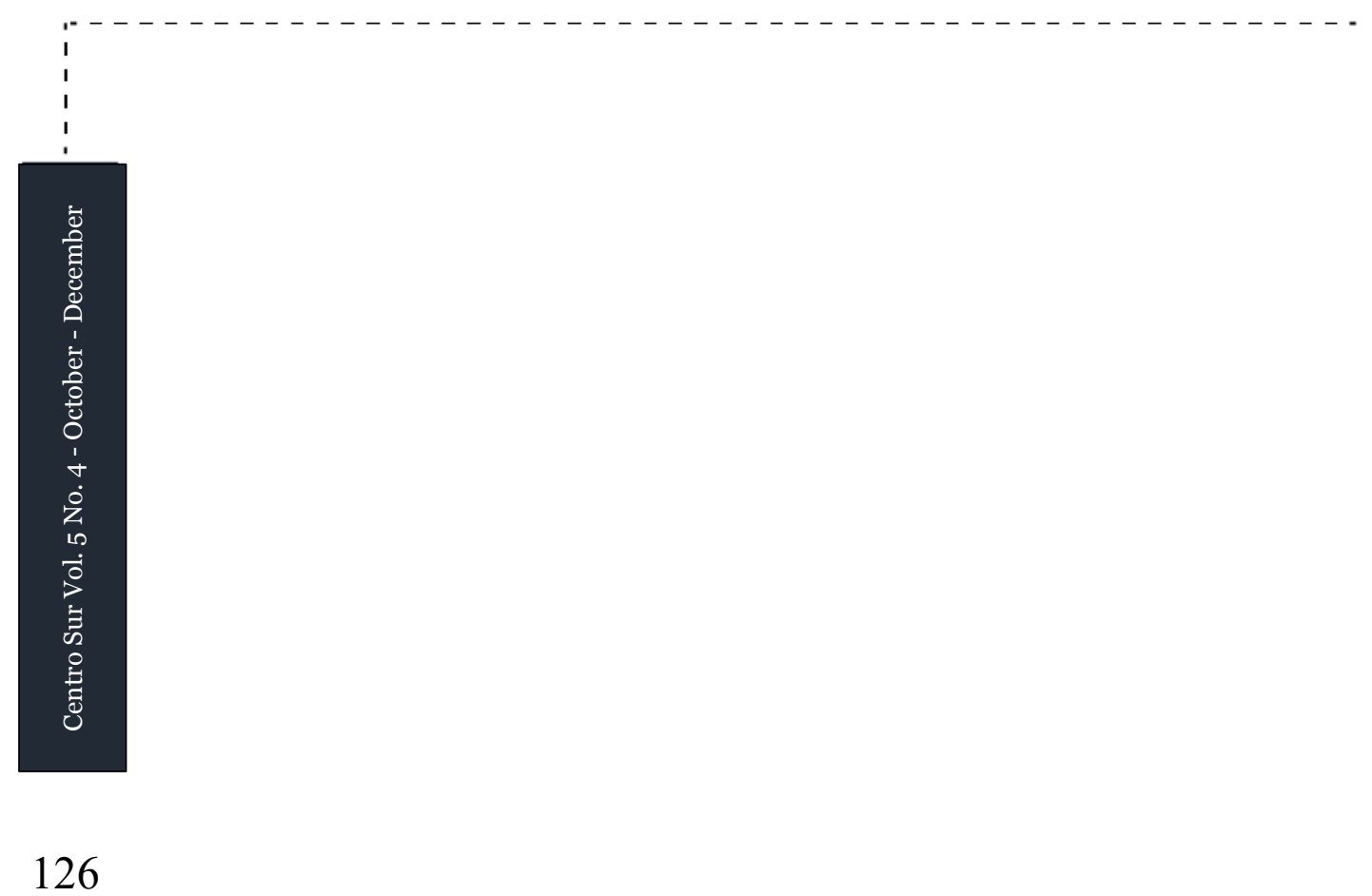

